\title{
Soil degradation processes in the Italian agricultural and forest ecosystems
}

\author{
Edoardo A.C. Costantini, Romina Lorenzetti \\ Consiglio per la Ricerca e la Sperimentazione in Agricoltura - Centro di Ricerca per l'Agrobiologia \\ e la Pedologia, Firenze, Italy
}

\begin{abstract}
A number of processes of degradation threaten soil functions. Ten of them are acknowledged by the European Union and fifteen by the Organisation for Economic Co-operation and Development (OECD), but at least another seven have been indicated by different authors in Italy and in other parts of the world. This short review paper summarizes the nature, economic relevance, and territorial impact of soil degradation in Italy, and with reference to Europe as a whole, and highlights the most relevant research needs in soil conservation. The direct annual costs of the main soil degradation processes are estimated to be over 38,000,000,000 euro per year in Europe as a whole, while in Italy, only for landslides, floods, and soil erosion, costs amount to $900,000,000$ euro. Loss of the ability to produce food commodities because of soil degradation is particularly important in Italy, since selfsufficiency in food has recently decreased to less than $80 \%$ and Italian agricultural soils are hit by several problems, such as limited soil drainage, unfavorable texture and stoniness, shallow rooting depth, and poor chemical properties. On average, soil sealing, reduction in organic matter, and soil compaction in Italy are comparable with those of many other countries, but the occurrence of soil erosion, floods, and
\end{abstract}

Correspondence: Edoardo A.C. Costantini, Consiglio per la Ricerca e la Sperimentazione in Agricoltura - Centro di Ricerca per l'Agrobiologia e la Pedologia, Piazza M. D’Azeglio 30, Firenze, Italy.

Tel. +39.055.2491222 - Fax: +39.055 .241485 .

E-mail: edoardo.costantini@entecra.it

Key words: soil organic carbon, geodatabase, bulk density, irrigation, salinity, sodicity, land planning.

Conference presentation: AISSA Palermo, 2012. Represented society at AISSA: Italian Soil Science Society (SISS) and the Italian Society of Pedology (SIPe).

Acknowledgments: the authors thanks prof. Fabio Terribile, President of the Italian Society of Pedology, Sergio Pellegrini, of the Agrobiology and Pedology Research Centre, and the anonymous referees, for their useful comments and suggestions.

Received for publication: 5 April 2013.

Revision received: 30 July 2013.

Accepted for publication: 24 August 2013.

() Copyright E.A.C. Costantini and R. Lorenzetti, 2013

Licensee PAGEPress, Italy

Italian Journal of Agronomy 2013; 8:e28

doi:10.4081/ija.2013.e28

This article is distributed under the terms of the Creative Commons Attribution Noncommercial License (by-nc 3.0) which permits any noncommercial use, distribution, and reproduction in any medium, provided the original author(s) and source are credited. landslides is more widespread than in most parts of Europe, and also the presence of salt-affected soils is becoming a major worry. The fight against soil degradation in Italy is certainly more difficult than in other countries because of the high environmental variability. However, according to the current trends, Italy is mostly probably destined not to achieve the European objective to significantly reduce main soil degradation processes by the year 2020 . There are several research needs in the field of soil conservation in Italy. These include: i) a better basic knowledge about many soil degradation processes and of pedodiversity; ii) reliable, sensitive, and locally validated models for main degradation processes; iii) assessment of resilience of different soils against degradation processes, as well as of their reaction to the measures foreseen in the current European agricultural policy.

\section{Introduction}

At the conference of the Italian Association of Agricultural Scientific Societies (Associazione Italiana Società Scientifiche Agrarie, AISSA) held in Palermo, Sicily ( $28^{\text {th }}-29^{\text {th }}$ November 2012), a presentation was given on Soil degradation processes in the Italian agricultural and forest ecosystems on behalf of the Italian Soil Science Society (SISS) and the Italian Society of Pedology (SIPe). This paper is the follow up of that report and presents the state of the art of soil degradation in Italy from a scientific standpoint. The aim of this short review is to illustrate the nature, economic relevance, and territorial impact of soil degradation in the Italian agricultural and forest ecosystems and in a European context. It also highlights the most important research needs and perspectives of soil conservation.

\section{Soil functions and soil degradation processes}

Soil is a multi-phase and complex natural system, which tends to self-organize according to the factors of pedogenesis (Figure 1). Figure 1 shows a soil profile in the Veneto Po Plain, on a terrace formed by the river Adige. Under the first $30 \mathrm{~cm}$ of the plough layer, where macroporosity is enhanced by cultivation and accumulation of organic matter, there is a structured and slightly rubified horizon that gradually passes to the fine sandy fluvial parent material at a depth of approximately $70 \mathrm{~cm}$. The groundwater fluctuates around approximately one meter from the surface. The millennial physical, biological, and chemical transformation of the unweathered sand into soil has allowed the development of its major functions, i.e. the biomass production for agricultural uses and the filtering of pollutants, which protects groundwater from contamination. The self-organization process is finite in time and tends to reach a steady state in which entropy is minimized (Addiscott, 2010; Targulian and Krasilnikov, 2007). Soil self-organization can be observed on different levels (Phillips et al., 1999; Phillips, 1995) and in the context of field survey, it can be understood by the arrangement of its constituents in specific and distinctive 
forms, namely soil horizons and pedofeatures. From an eco-systemic standpoint, soil self-organization is part of a country's natural heritage, but it also has economic value because the interests of soil self-organization and ecosystem services run parallel (Robinson et al., 2009). Therefore, soil degradation can be defined as the process leading to the loss of the self-organization ability of the soil constituents, due to either natural causes or human activities.

Another definition of soil degradation, more specifically directed towards emphasizing the loss of soil functions, is that given by the Organisation for Economic Co-operation and Development (OECD) which states that soil degradation refers to the process(es) by which soil declines in quality and is thus made less fit for a specific purpose, such as crop production (OECD, 2001).

In reality, soil functions are multi-fold, and many of them have still not been completely investigated. The European Union summarizes soil functions in seven categories (European Commission, 2006a; JRC, 2011): i) Biomass production, including that in agriculture and forestry; ii) Storing, filtering and transforming nutrients, substances and water; iii) Biodiversity pool, such as habitats, species and genes; iv) Physical and cultural environment for humans and human activities; v) Source of raw materials; vi) Acting as a carbon pool; vii) Archive of geological and archaeological heritage.

Several factors could impair soil function. The European Union has acknowledged eight threats to soil functions, or degradation processes: i) Water and wind erosion; ii) Decline in organic matter; iii) Contamination; iv) Sealing; v) Compaction; vi) Soil biodiversity loss; vii) Salinization; viii) Floods and landslides (European Commission, 2006a).

Two others were later added: ix) Desertification; $x$ ) Acidification (JRC, 2011; European Commission, 2012).

The OECD also considers submersion, surface crusts and compact layer formation along the profile, deterioration of the soil structure, accumulation of toxic substances, as well as loss of nutrients (OECD, 2001). Other soil degradation processes have been indicated by several authors, in particular, soil losses for suffusion in karst and granite (Li and Zhou, 1999; Durgin, 1984), modification in cracking of Vertisols due to climate change (Pal et al., 2009), increased soil aridity as a consequence of reduced water holding capacity and climate change (Costantini et al., 2009; EEA, 2012), colder soil temperature regime because of the reduction in snow cover (Freppaz et al., 2008), loss of pedodiversity as a consequence of human activities (Dazzi and Lo Papa, 2013; Dazzi and Monteleone 2007; Costantini and L'Abate, 2009), peat degradation and loss of hydric properties following drainage (Fornasiero et al., 2003).

\section{Relevance of soil degradation}

Some attempts have been made to estimate the costs of soil degradation. In the accompanying document to the thematic strategy for soil protection (European Commission, 2006b), the impact assessment of only the direct annual costs of the main soil degradation processes in Europe is estimated to amount to over $38,000,000,000$ euro per year. In Italy, the direct costs of the hydrogeological instability experienced during the last ten years, caused by landslides, floods, and soil erosion, is estimated to be as high as 9,000,000,000 euro (ISPRA, 2013). It goes without saying that hydrogeological instability has a huge impact on human safety. For example, only in the period 2004-2010 there were 67 casualties in 14 landslides (http:/www.meteoportaleitalia.it/).

Besides danger to the population and damage caused to buildings and infrastructures, soil degradation has a big affect on the agricultural and forestry sector. In this case, the costs of soil degradation can also be estimated in terms of loss of potential agricultural production capability. The term land take refers to the area of land that is taken by the infrastructure itself and by other facilities that necessarily go along with the infrastructure, such as filling stations on roads and railways stations (http://glossary.eea.europa.eu). On a European level, the loss of winter wheat yield caused by land take during the years 1990 to 2006 has been evaluated at over 6 million tonnes (JRC, 2011). For Italy, the potential loss is assessed to be as much as 474,400 tonnes per year.

The loss of ability to produce food commodities is particularly relevant for Italy as a country, especially if we consider that: i) the price index of cereals has increased considerably during the last ten years (>70\%) (FA0, 2013); ii) crop yields per hectare (ha) of main crops have almost reached a plateau; iii) Italy's self-sufficiency in food has decreased from more than $90 \%$ in the 1990 s to less than $80 \%$ since 2010 (MiPAAF, 2012).

A major consequence of soil degradation in Italy is that it reduces the agricultural production potential of soils that are in many cases already disadvantaged with respect to European standards. It is well known that agricultural areas in Italy are mainly concentrated on the plains and low hilly lands (Figure 2). A recent study actually demonstrates that, according to the European legislation (REG. CE n. 1698/2005), approx-

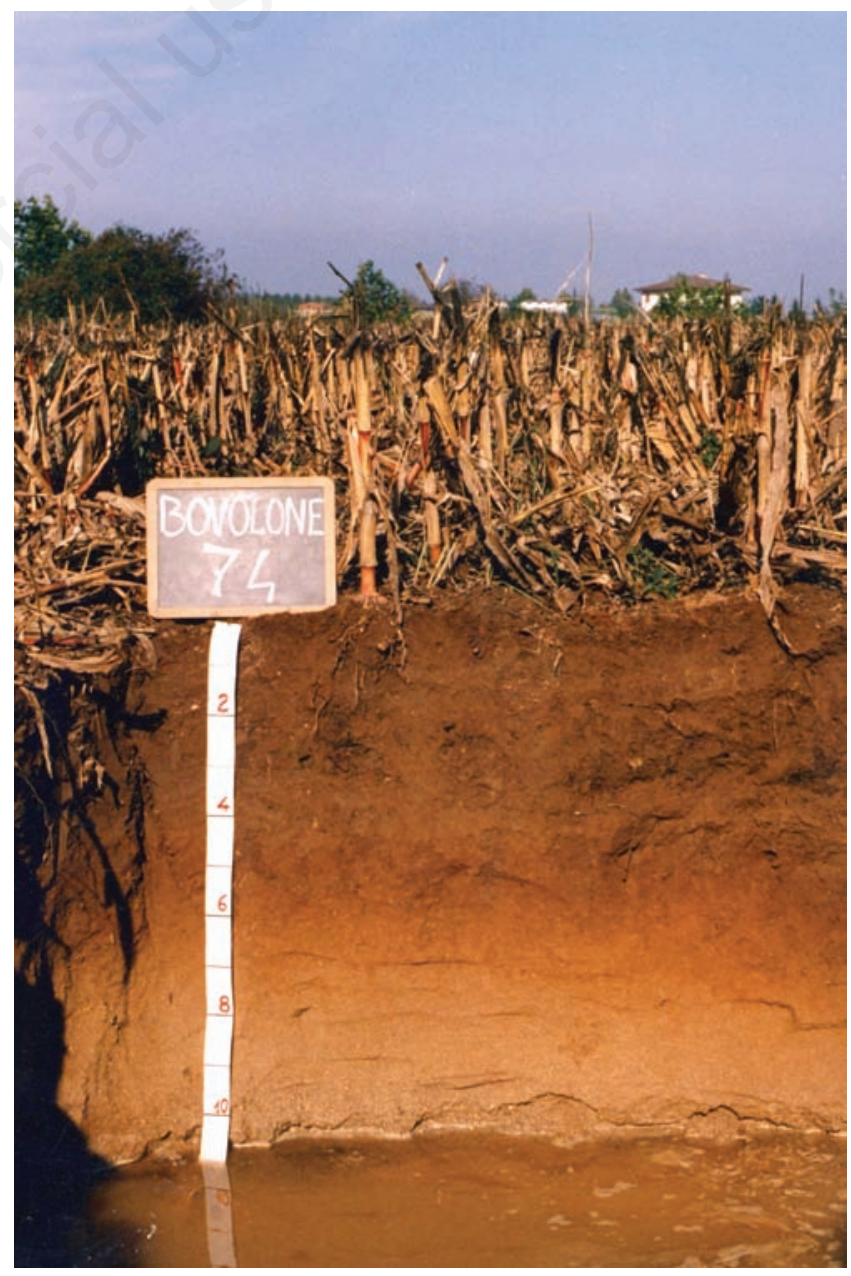

Figure 1. Soil profile on the Veneto Po Plain, northwestern Italy, on a terrace formed by the river Adige. 
imately $82 \%$ of the total 12.9 million ha of land used for agricultural purposes in the year 2011 must be considered less favored (MiPAAF, 2013). It is interesting to note that among the bio-physical criteria used to single out municipalities with predominantly less favored agricultural lands, soil constraints (limited soil drainage, unfavorable texture and stoniness, shallow rooting depth, poor chemical properties) actually play the most important role (Figure 3 ).

\section{Impact of soil degradation in Italy and Europe}

The European Commission has recognized soil sealing, soil erosion, and organic matter decline as the soil degradation processes on which member states should concentrate their main efforts, in consideration of their economic and environmental relevance (Resource Efficiency Roadmap: COM no. 571 of 20/9/2011). In this respect, the following objectives for the year 2020 have been recommended: i) reducing annual land take, i.e. the increase of artificial land should not exceed $800 \mathrm{~km}^{2}$ per year in the EU; ii) there should be an at least $25 \%$ reduction in areas of land in the EU that are subject to a soil erosion rate of more than 10 tonnes per ha per year; iii) there should be no overall decrease in soil organic matter levels and no increase in soils currently with less than $3.5 \%$ organic matter.

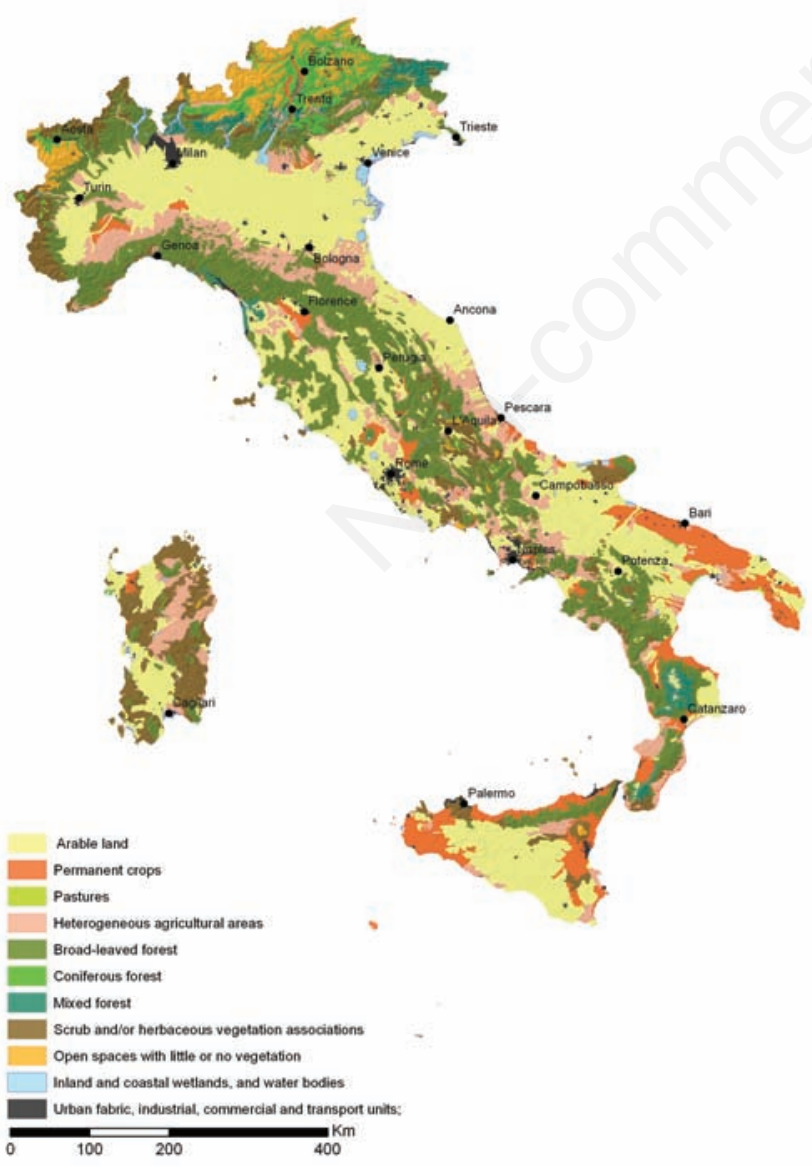

Figure 2. Main land uses in Italy.

\section{Soil sealing and land take}

Soil sealing is the most harmful process of soil degradation, since it often implies the complete loss of biological functions, it is almost irreversible, and threatens a vast amount of soils, in particular, those most fertile. The area of the soil surface covered with an impermeable material is today estimated to be approximately $9 \%$ of the total European Union. During the years 1990-2000, the sealed area in the then $15 \mathrm{EU}$ member states increased by $6 \%$; at present, the demand for both transport infrastructures and new buildings continues to rise (JRC, 2011).

The territory directly covered by settlements in Italy increased by $166 \%$ between 1956 and 2012 , at a daily rate of approximately 100 ha (Consiglio dei Ministri, 2012) and currently involves $4.9 \%$ of the country (ISPRA, 2013). This does not include the network of roads (approx. $1000 \mathrm{~km}$ ) and railways (approx. 16,000 km).

Per capita soil consumption doubled from $2.8 \%$ in $1956\left(170 \mathrm{~m}^{2}\right.$ per capita) to $5.7 \%$ in 1996 (303 $\mathrm{m}^{2}$ per capita), and reached $6.9 \%$ in 2010 (343 $\mathrm{m}^{2}$ per capita) (ISPRA, 2013). Since the beginning of the $1980 \mathrm{~s}$, the increase in sealed areas was decoupled from population growth, indicating that land take and urban development have generally occurred through dispersed residential settlements, as well as commercial and infrastructure expansion (Munafò et al., 2013). The highest proportion of sealed plots has been observed in northern Italy. In contrast, the per capita growth rate of land take is higher in southern Italy.

A more recent threat jeopardizing agricultural soils in Italy is the

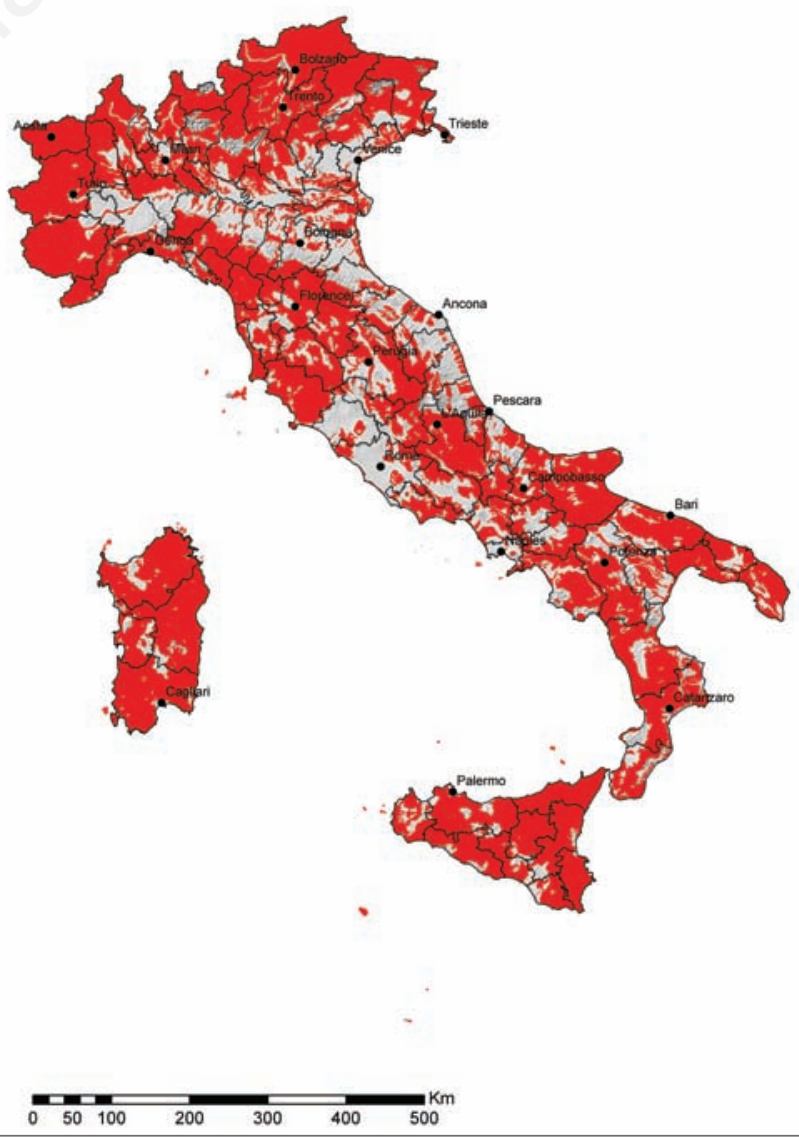

Figure 3. Municipalities with dominant agricultural soils showing physical-chemical constraints according to the European standard. 
installations of photovoltaic devices to produce electricity that occupy agricultural land of different dimensions. They are mostly located on flat areas or valley floors that have high productive value. It is still not understood how photovoltaic devices modify or impair soil function. However, the land used for this purpose is certainly no longer agriculturally productive.

Although no estimates are available as to the number of hectares covered or the kind of soils involved, the total number of installations gives an indication of how widespread their use is. At the end of 2009, there were 71,284 photovoltaic installations in Italy for a productive capacity of 1142.4 MW (Dazzi and Lo Papa, 2013). At present, only some regional administrations have started to consider the problem of legislation, e.g. Tuscany (http:/www.arpat.toscana.it/documentazione/normativa/normativa-regionale-toscana/2013/delibera-consiglioregionale-toscana-n.15-2013).

In conclusion, unless new national legislation is introduced, Italy, like the rest of Europe, is most probably destined to fail to achieve the European objective to reduce the rate of annual land take by 2020 .

\section{Soil erosion and landslides}

The European Environment Agency (EEA) estimates that 115 million ha, or 12\% of Europe's total land area, are affected by water erosion, and that 42 million ha are affected by wind erosion (JRC, 2011). The OECD estimates that over $20 \%$ of Italian agricultural land fell within the moderate to severe risk classes for soil water erosion (equal or more than 11 t.ha ${ }^{-1} \cdot y^{-1}$ ) in the period 2000-2002. The Institute for

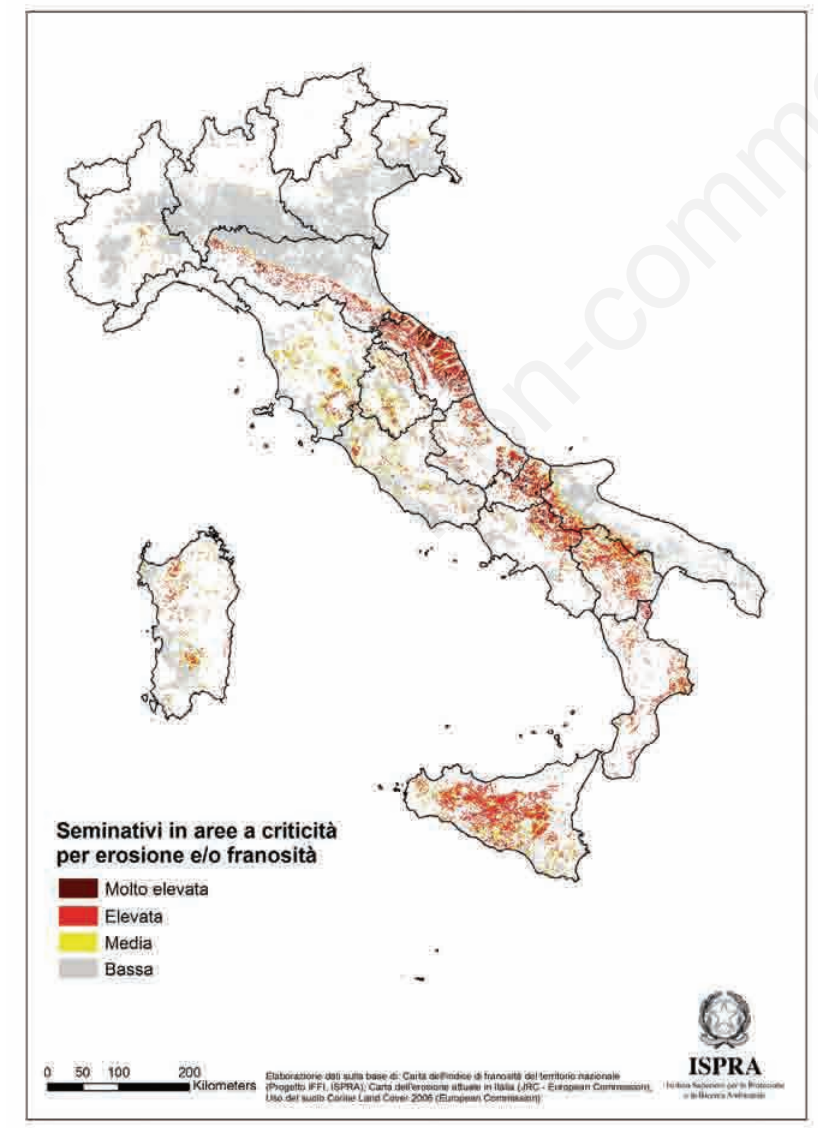

Figure 4. Row crop distribution in areas of different sensitivity to erosion and landslide (ISPRA, 2013).
Environmental Protection and Research has mapped some 485,000 landslides in Italy, taking up 2,070,000 ha, i.e. $6.9 \%$ of the country, and has mapped the areas of row crops (Figure 4) and woodland (Figure 5) at different degrees of criticality (ISPRA, 2013).

Critical areas at risk of soil erosion are located in central and southern Italy, on slopes where agricultural lands are intensively cultivated and there are outcrops of marine sediments of the Neocene. In contrast, woodlands with the highest risk of landslides are more widespread in northern Italy, on the steep slopes of the Alps and the Apennines.

It must be stressed that most shallow landslides concern the soil cover, not the substratum, and they are caused by a complex interaction between climate, morphology, soil characteristics, forest land use, and management. Therefore, only taking into consideration the nature of the soil it is possible to understand the causes and to identify the technical measures to be taken to prevent this kind of mass movement. For example, it has been well documented that the improper management of woodland on Andosols placed on fragile morphologies can dramatically increase the risk of landslides (lamarino and Terribile, 2008; Terribile et al., 2007) (Figure 6).

Under the current legislation and land management policies, Italy will probably not achieve the 2020 European target for soil erosion rates. Fluctuations are expected and these reflect the patterns of land use and climate change. However, the lack of robust and validated models, which include the effect of land management, means that reliable quantitative projections are currently not available, neither for Italy nor for Europe as a whole (EEA, 2012).

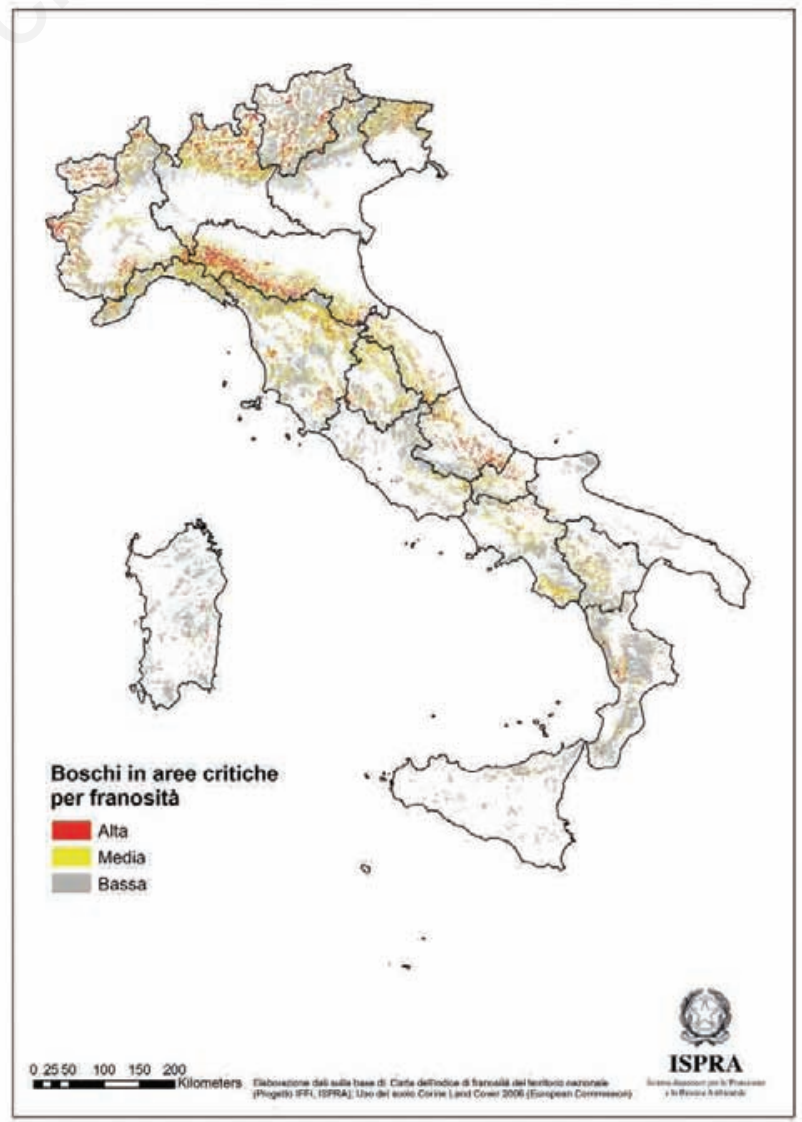

Figure 5. Woodland distribution in areas of different sensitivity to landslide (ISPRA, 2013). 
Different forms of soil degradation often occur at the same place and time as a consequence of a triggering event. In Figure 7 we can see how excessive land leveling deeply scalped the soil, not only provoking the loss of material and increasing the risk of floods and landslides, but also worsening soil organic matter content and biodiversity, which in turn loosened soil structure and favored surface crust formation.

\section{Organic matter decline}

It has been estimated that $45 \%$ of European soils have a low or very low organic carbon content $\left(0-2 \mathrm{~g} .100 \mathrm{~g}^{-1}\right)$ and $45 \%$ have a medium content (2-6 g. $\left.100 \mathrm{~g}^{-1}\right)$ (JRC, 2011). Data downscaled to Italy indicated that almost $23 \%$ of Italian soils have less than $1 \mathrm{~g} .100 \mathrm{~g}^{-1}$ of organic car-

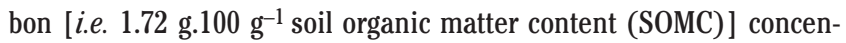
trated in the regions of Apulia, Sicily and Sardinia (Jones et al., 2005; Panagos et al., 2008; Schils et al., 2008).

The results reported by many authors suggest that changes in land use and management might be responsible for the variations in SOMC in the country as a whole and on a regional level (Smith et al., 2012). The information stored in the national soil information system of Italy database confirms the influence of land use and management on SOMC in this country (Table 1). Data on SOMC in the surface horizons are stored for 23,516 sites. There is a remarkable range in SOMC mean values between different crops and uncultivated land. In particular, rice paddies and other arable lands (urban soils included) show mean values of between $2.0 \%$ and $2.3 \%$, mean SOMC values for meadows and other less intensively or uncultivated areas vary between $3.0 \%$ and $3.9 \%$, whereas in the different kind of woodlands and natural areas these values can reach $6.0 \%$. However, the high values of standard deviation, which are of the same order of magnitude as means, or even higher, indicate that variations of land management and local conditions play an important role in regulating SOMC.

Therefore, we can expect to see important changes in SOMC over time. On a national basis, Fantappiè et al. (2010) estimated, by means of a multivariate spatial regression model, a significant decrease in SOMC (from 2.53 to $2.02 \mathrm{~g} .100 \mathrm{~g}^{-1}$ ) between the 30 -year period 1961 and 1990, and the period 1991 and 2009. Meadows (from 2.69 to 1.93 g. $100 \mathrm{~g}^{-1}$ ) were more affected than forests (from 3.34 to $2.77 \mathrm{~g} .100 \mathrm{~g}^{-1}$ ) and arable lands (from 1.55 to $1.36 \mathrm{~g} .100 \mathrm{~g}^{-1}$ ). The decrease was most likely due to the changes in land use and management, while the observed climate change occurred between the two periods was not seen to play a key role. Nevertheless, climate may have had an influence in meadows and in arable lands with a moderate or high mean annual precipitation decrease $\left(<-100 \mathrm{~mm} \cdot \mathrm{y}^{-1}\right)$ and a moderate to high

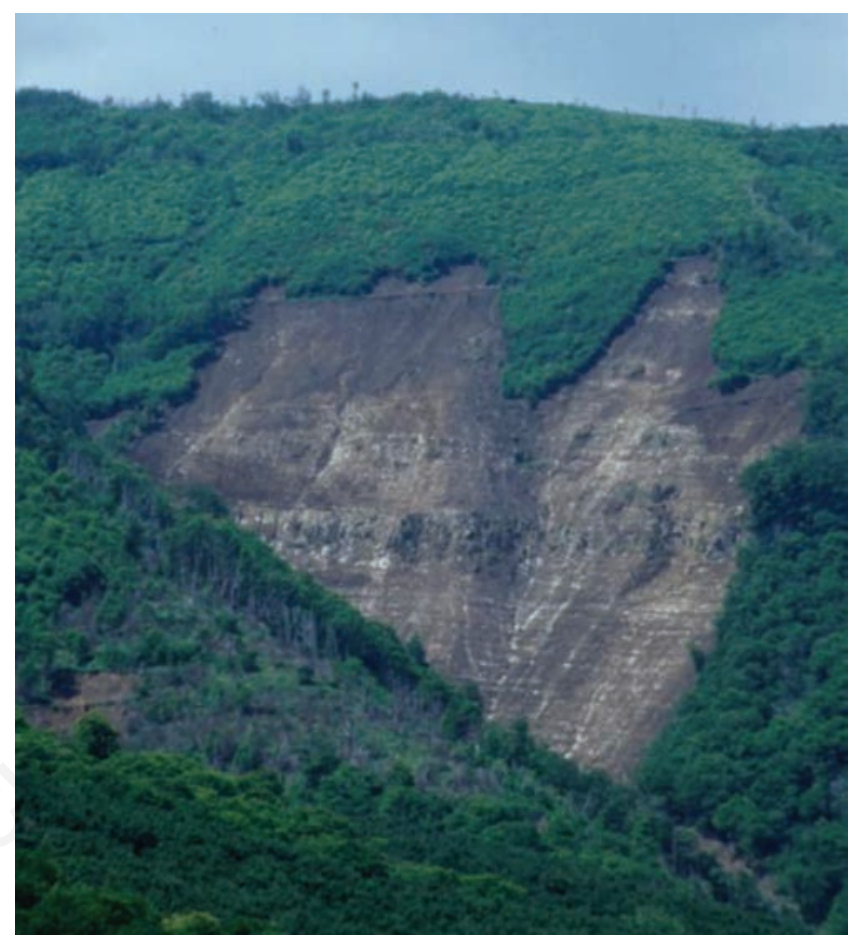

Figure 6. Shallow landslides in woodlands often concern the soil cover and are triggered by an improper land management.

Table 1. Basic statistics on soil organic matter content and land use type in Italy (source: national soil database, available from: http://www.soilmaps.it).

\begin{tabular}{|c|c|c|c|c|c|}
\hline Land use & Mean & Standard deviation & Sites (n) & $\begin{array}{l}\text { SOMC }<1.72 \\
\text { ( } \% \text { of sites) }\end{array}$ & $\begin{array}{l}\text { SOMC }<3.5 \\
(\% \text { of sites })\end{array}$ \\
\hline Rice paddies & 2.02 & 1.68 & 135 & 43 & 96 \\
\hline Vineyards & 2.09 & 1.94 & 2105 & 48 & 91 \\
\hline Vegetables & 2.11 & 1.87 & 236 & 44 & 93 \\
\hline Agricultural mixed & 2.15 & 1.87 & 605 & 48 & 90 \\
\hline Row crops & 2.23 & 1.84 & 11,084 & 38 & 90 \\
\hline Olive tree groves & 2.29 & 1.87 & 1816 & 41 & 85 \\
\hline Urban soils & 2.32 & 1.93 & 102 & 43 & 85 \\
\hline Orchards & 2.34 & 1.54 & 568 & 36 & 85 \\
\hline Meadows & 3.04 & 3.35 & 1982 & 30 & 75 \\
\hline Agroforestry & 3.80 & 6.10 & 454 & 27 & 71 \\
\hline Wetlands & 3.94 & 4.50 & 17 & 47 & 65 \\
\hline Mediterranean maquis & 4.95 & 5.85 & 254 & 24 & 52 \\
\hline Rangeland & 5.09 & 5.01 & 1665 & 19 & 53 \\
\hline Woodlands & 6.00 & 5.87 & 2493 & 12 & 38 \\
\hline All land uses & 2.95 & 3.41 & 23,516 & 34 & 80 \\
\hline
\end{tabular}


increase in mean annual temperature $\left(>0.62^{\circ} \mathrm{C}\right)$, largely distributed in Apulia, Sardinia, the northern Apennines, and the pre-Alps (Fantappiè et al., 2011).

Critical levels of SOMC are still a question of debate and are thought to differ according to the kind of soil function (e.g. plant mineral nutrition, soil physical properties), particle size, and climatic region (Loveland and Webb, 2003). Some authors considered the threshold of $1.72 \mathrm{~g} .100 \mathrm{~g}^{-1}$ as the minimum value to assure the supply of elements to plants and to limit the passage of pollutants from the soil surface to the underlying water table (Johnston, 1991; Körschens et al., 1998; Huber et al., 2008; APAT, 2007). The SOMC for approximately $34 \%$ of the Italian topsoils studied falls below that limit, and $80 \%$ falls below the target threshold of $3.5 \mathrm{~g} .100 \mathrm{~g}^{-1}$ (i.e. the established target in the above mentioned EU Resource Efficiency Roadmap). Therefore, it is possible to conclude that approximately one-third of a representative set of Italian soils can be considered to be degraded in some degree for a number of their basic functions.

Degraded soils are mainly under agricultural cultivation, but they are also present in a significant proportion of the semi-natural land covers. Complying with the objectives stated in the Resource Efficiency Roadmap for the year 2020, and restoring the fertility of Italian soils, would require a major effort to launch a nation wide campaign dedicated to the implementation of specific, locally tailored agro-techniques across all agricultural land uses.

Among soil management practices, irrigation is thought to have a considerable effect on the physical and chemical properties of the soil. The impact of irrigation on soil organic matter sequestration, however, is controversial, depending on the interaction with many other agricultural practices, such as type of cultivation, fertilization, volumes and time of irrigation. Some authors claim that, in the Mediterranean environment, irrigation causes a decrease in SOMC of arable lands because it enhances microbiological activity and mineralization (AlvaroFuentes and Paustian, 2011). However, others, on a broader scale, report the opposite (Chen et al., 2011).

The data stored on the national soil database, limited to the regions of central and southern Italy, indicate lower SOMC values for all crops under irrigation, particularly for vegetables, row crops, and orchards (Table 2). Vineyards, olive tree groves, and mixed crops show fewer dif- ferences, and the same holds true for meadows. Irrigation of tree crops is sometimes combined with a permanent grass cover that avoids soil surface cultivation during the crop season. It is well known that this

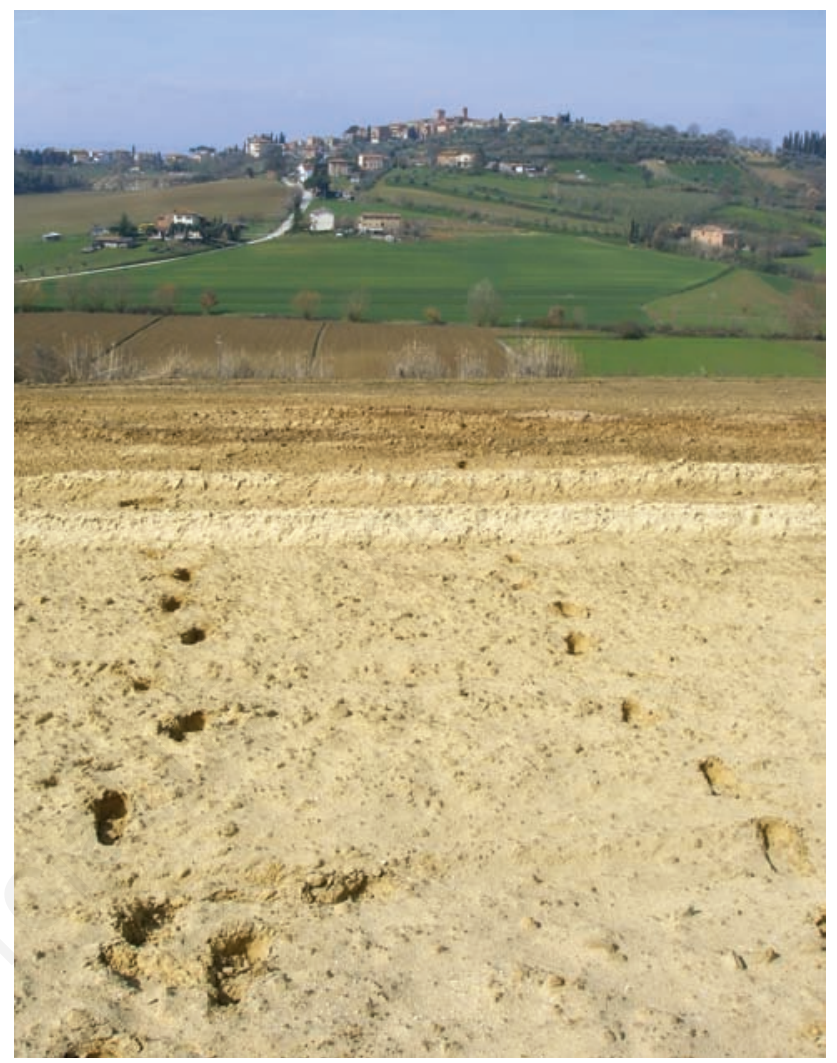

Figure 7. Different forms of soil degradation often occur at the same place.

Table 2. Basic statistics on soil organic matter content and land use type with respect to irrigation in the regions of central and southern Italy (source: national soil database).

\begin{tabular}{lccc}
\hline Land use & SOMC & Standard error & Sites (n) \\
Vegetables irrigated & 1.90 & \pm 0.09 & 109 \\
Vegetables not irrigated & 2.38 & \pm 0.28 & 80 \\
\hline Row crops irrigated & 1.96 & \pm 0.04 & 1517 \\
Row crops not irrigated & 2.06 & \pm 0.03 & 2288 \\
\hline Orchards irrigated & 2.39 & \pm 0.12 & 277 \\
Orchards not irrigated & 2.80 & \pm 0.13 & 289 \\
\hline Vineyards irrigated & 2.05 & \pm 0.08 & 405 \\
Vineyards not irrigated & 2.06 & \pm 0.09 & 438 \\
\hline Olive tree groves irrigated & 2.00 & \pm 0.07 & 472 \\
Olive tree groves not irrigated & 2.08 & \pm 0.05 & 855 \\
\hline Agricultural mixed irrigated & 1.67 & \pm 0.16 & 37 \\
Agricultural mixed not irrigated & 2.04 & \pm 0.11 & 153 \\
\hline Meadows irrigated & 2.24 & \pm 0.19 & 217 \\
Meadows not irrigated & 2.48 & \pm 0.17 & 392 \\
\hline All land uses irrigated & 2.03 & \pm 0.11 & 3040 \\
All land uses not irrigated & 2.27 & \pm 0.12 & 4495
\end{tabular}

SOMC, soil organic matter content (g.100 $\left.\mathrm{g}^{-1}\right)$. 
practice, aimed at eliminating weeds and reducing capillary water losses in rain-fed cultivation, usually leads to a decrease in SOMC (Conant et al., 2001).

\section{Compaction}

After soil sealing, erosion, and organic matter decline, compaction is probably the most extensive degradation process affecting soil resources of Europe and Italy. Compaction is strictly bound to soil structure deterioration that is often induced by the use of heavy machinery on soils with a low organic matter content. Therefore, progressive soil compaction frequently goes along with organic matter decline.

Compacted soils, showing bulk density (BD) values over 1.4 g.cm ${ }^{3}$ generally have bad structure conditions, few macropores, show impediments to regular air and water flows, and limit microbiological activities (Pagliai et al., 2000).

Estimates of areas at risk of soil compaction vary according to the authors. A recent approximation classifies around 36\% of European soils as having high or very high susceptibility to compaction, while other sources report $32 \%$ of soils being highly vulnerable and $18 \%$ moderately affected (JRC, 2011).

Italian soils are considered to be affected to a similar extent (APAT, 2007). The national soil database indicates that 2186 out of 8125 sites where BD was measured are compacted (27\%). They are present in all the cultivated hill lands and on the plains of Italy, particularly when soil texture is fine and organic carbon is low. Table 3 shows a strong relationship between land use and soil compaction. In fact, rice paddies, wetlands, degraded natural areas, and rain-fed row crops are those contexts in which soils more frequently have BD values over $1.4 \mathrm{~g} . \mathrm{cm}^{3}$. Mountain meadows and woodlands, but also irrigated row crops, have the most friable and porous soils (Figure 8).

\section{Salinization, sodification, and alkalinization}

Salinization is the accumulation of soluble salts (mainly chloride, sulphate, carbonate and bicarbonate of sodium, magnesium, calcium, and potassium) in the soil profile. Sodification is the progressive saturation of the exchange complex with sodium (mainly from sodium carbonate), while alkalinisation is the increase in $\mathrm{pH}$ reaction in the soil solution up to or over 8.5.

Soil salinization in Europe is estimated to affect between 1 to 3 mil- lion ha, mainly in the countries of the Mediterranean (JRC, 2011). The phenomena is thought to be increasing as a consequence of the rise in evapotranspiration demand caused by the ongoing climate change and, to a greater extent, by the harsher competition seen every day between the different needs for water. In fact, this latter factor means that the water used for irrigation is of an increasingly poor quality.

In Italy, salinity and sodicity are commonly believed to have only a marginal effect (Tóth et al., 2008) and to be concentrated along some coastlines and in Sicily (Dazzi, 2006). However, studies on gypsiferous soils and on soils with parent materials rich in sodium (Dazzi et al., 2005; Busoni et al., 1995) have demonstrated that the presence of soils with a Saline or Sodic horizon might be more extensive than currently estimated, and, in particular, much larger than that of Solonchak and Solonetz.

In addition to the scientific results, regional soil surveys have report-

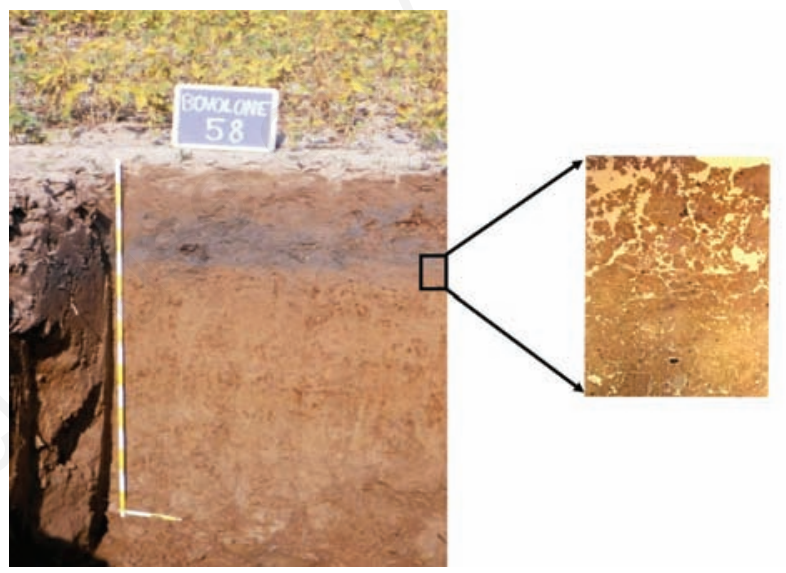

Figure 8. Soil of the Po plain with a compacted subsurface horizon (plow pan) showing hydromorphy caused by temporal waterlogging. The thin soil section shows the change in macroporosity at the passage between the ploughed horizon and the plow pan (thin section courtesy of M. Pagliai).

Table 3. Basic statistics on soil bulk density with respect to land use type in Italy (source: national soil database).

\begin{tabular}{|c|c|c|c|c|}
\hline Land use & Mean & Standard error & Sites (n) & $\mathrm{BD}>1.4 \%$ \\
\hline Rice paddies & 1.45 & \pm 0.02 & 86 & 62 \\
\hline Wetlands & 1.38 & \pm 0.07 & 5 & 40 \\
\hline Rain-fed row crops & 1.29 & \pm 0.00 & 3984 & 33 \\
\hline Degraded natural areas & 1.28 & \pm 0.14 & 5 & 40 \\
\hline Vegetables & 1.27 & \pm 0.02 & 119 & 29 \\
\hline Meadows & 1.23 & \pm 0.01 & 523 & 25 \\
\hline Orchards & 1.23 & \pm 0.01 & 456 & 24 \\
\hline Urban soils & 1.22 & \pm 0.06 & 19 & 21 \\
\hline Olive tree groves & 1.21 & \pm 0.01 & 722 & 23 \\
\hline Vineyards & 1.21 & \pm 0.01 & 561 & 27 \\
\hline Agricultural mixed & 1.20 & \pm 0.02 & 206 & 23 \\
\hline Irrigated row crops & 1.16 & \pm 0.01 & 470 & 12 \\
\hline Woodlands & 1.14 & \pm 0.01 & 685 & 14 \\
\hline Mountain meadows & 1.10 & \pm 0.01 & 284 & 11 \\
\hline All land uses & 1.24 & \pm 0.003 & 8125 & 27 \\
\hline
\end{tabular}

BD, bulk density $\left(\mathrm{g} . \mathrm{cm}^{-3}\right)$. 
ed the presence of saline and sodic soils in different parts of the central and southern regions, and also in northern Italy (Figure 9). The world reference base for soil resources soil classification system currently considers many kinds of salt-affected soils, besides Solonchaks, Solonetz, and Gypsisols. In particular, the sodic qualifier applies to soils that have $15 \%$ or more exchangeable sodium $(\mathrm{Na})$ plus magnesium on the exchange complex within $50 \mathrm{~cm}$ of the soil surface throughout. The Hyposodic qualifier considers eligible soils that have $6 \%$ or more exchangeable $\mathrm{Na}$ on the exchange complex in a layer, $20 \mathrm{~cm}$ or more thick, within $100 \mathrm{~cm}$ of the soil surface. Salic soils must have a salic horizon starting within $100 \mathrm{~cm}$ of the soil surface and hyposalic soils an ECe of $4 \mathrm{dS} \mathrm{m}^{-1}$ or more at $25^{\circ} \mathrm{C}$ in some layer within $100 \mathrm{~cm}$ of the soil surface. A salic horizon must have: i) averaged over its depth at some time of the year, an electrical conductivity of the saturation extract (ECe) of $15 \mathrm{dS} \mathrm{m}^{-1}$ or more at $25^{\circ} \mathrm{C}$, or an ECe of $8 \mathrm{dS} \mathrm{m}^{-1}$ or more at $25^{\circ} \mathrm{C}$ if the $\mathrm{pH}\left(\mathrm{H}_{2} \mathrm{O}\right)$ of the saturation extract is 8.5 or more; and ii) averaged over its depth at some time of the year, a product of thickness (in centimetres) and ECe (in $\mathrm{dS} \mathrm{m}^{-1}$ ) of 450 or more; and iii) a thickness of $15 \mathrm{~cm}$ or more. Several hundred profiles stored in the national soil database have at least one of the sodic, hyposodic, salic, hyposalic, and gypsic qualifiers; they belong to Vertisols, Cambisols, Regosols, Calcisols, and in a few cases to other soil classes. The distribution area of all kinds of salt-affected soils is $31,968 \mathrm{~km}^{2}$ (Figure 10). The presence of salt-affected soils is not only limited to the south of Italy or coastal areas, but to the north as well. However, the occurrence of soils influenced by salinity or sodicity in the topsoil is much less widespread than that of soils that are only affected at depth.

It has been reported that irrigation with bad quality water in Italy is on the increase and can raise soil salinity (Crescimanno et al., 2009). A data search through the national soil database for the electrical conductivity of irrigated and non-irrigated soils of southern Italy gave the results reported in Table 4 . The soil electrical conductivity was compared between 321 irrigated and 716 non-irrigated sites. All sites refer to the regions of southern Italy, where problems related to the use of bad quality water are more critical because of the limited supply of fresh river and lake water, and the high proportion of wells placed close to the Mediterranean coast. Nevertheless, average values of electrical conductivity point to low saline conditions. In particular, the outcomes show that a significant increase in salinity of irrigated soils is only present in vegetables and meadows, while in the other crops, irrigation either did not affect soil salinity significantly or contributed to salt leaching.

Saline and sodic soil distribution in Italy also depends on other agricultural practices, such as land leveling before crop plantation on soils formed from marine substrata (Figure 11). The extent of this kind of degraded soils is still not completely understood.

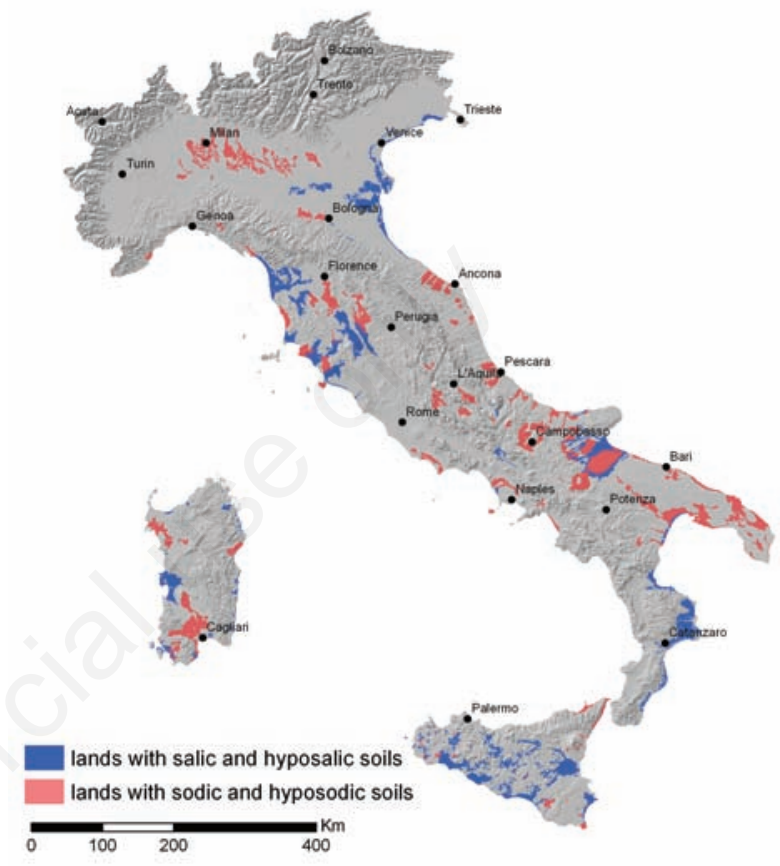

Figure 9. Lands with presence of salt-affected soils.

Table 4. Basic statistics on soil electrical conductivity $\left(\mathrm{dS} . \mathrm{m}^{-1}\right)$ with respect to land use type and irrigation (source: national soil database).

\begin{tabular}{lccc} 
Land use & Electrical conductivity & Standard error & \\
Vegetables irrigated & 0.51 & \pm 0.11 & 31 \\
Vegetables not irrigated & 0.33 & \pm 0.05 & 35 \\
\hline Meadows irrigated & 0.55 & \pm 0.30 & 27 \\
Meadows not irrigated & 0.32 & \pm 0.05 & 73 \\
\hline Row crops irrigated & 0.32 & \pm 0.03 & 119 \\
Row crops not irrigated & 0.48 & \pm 0.05 & 310 \\
\hline Orchards irrigated & 0.31 & \pm 0.05 & 34 \\
Orchards not irrigated & 0.58 & \pm 0.17 & 57 \\
\hline Vineyards irrigated & 0.29 & \pm 0.04 & 45 \\
Vineyards not irrigated & 0.38 & \pm 0.07 & 119 \\
\hline Olive tree groves irrigated & 0.23 & \pm 0.03 & 63 \\
Olive tree groves not irrigated & 0.32 & \pm 0.05 & 106 \\
\hline Agricultural mixed areas irrigated & 0.20 & \pm 0.01 & 2 \\
Agricultural mixed areas not irrigated & 0.27 & \pm 0.05 & 16 \\
\hline All land uses irrigated & 0.34 & \pm 0.08 & 321 \\
All land uses not irrigated & 0.38 & \pm 0.7 & 716 \\
\hline
\end{tabular}




\section{Driving forces of soil degradation}

Unfavorable climate quality and climate changes, unsustainable intensification of agricultural activities, and pattern of population growth are the processes considered to play the most important role in determining vulnerability to soil and land degradation in Italy (Salvati et al., 2011). According to four different scenarios, in the year 2015 up to $18-27 \%$ of the country will be affected in various degrees by land degradation (Salvati and Carlucci, 2013).

More sensitive terrain is mainly located in coastal and upland areas of southern Italy and the main islands and, to a lesser extent, in some plains of northern Italy where population density is higher (Costantini et al., 2009; Salvati et al., 2011). However, recent studies seem to indicate a tendency to dissociate population density and land degradation. As a matter of fact, since the 1980s, the population has increased in moderately vulnerable areas but has decreased where there is highly vulnerable land (Salvati, 2012).

Several studies have demonstrated that land policy, determined by

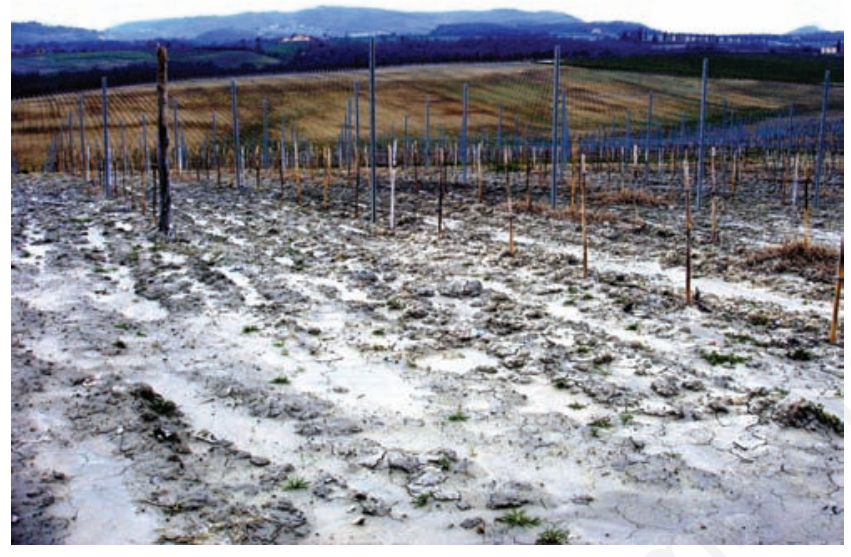

Figure 10. Outcrop of marine substratum in a vineyard in Tuscany, a consequence of excessive land leveling before crop plantation. Salt efflorescences and dead vines in the foreground, leopard-like spots of sodic soils in the background.

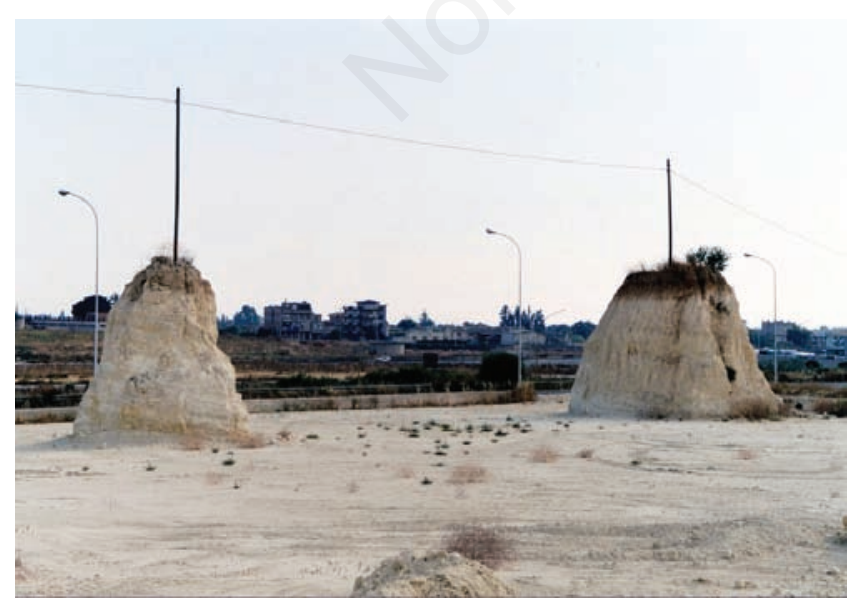

Figure 11. Earth movements are sometimes so extreme that topography is dramatically changed, soils are completed stripped, and pedodiversity disappears completey, like in this area of Sicily where land was leveled before tree plantation (photograph courtesy of C. Dazzi).
EU regulation and its practical application by local authorities and farmers, can either enhance or impair land use sustainability and soil conditions. Management practices introduced with the cross compliance Good Agricultural and Environmental Conditions (GAEC) standards were found to be effective in improving soil qualities (Bazzoffi et al., 2011), in particular, those that minimized soil disturbance and increased soil organic carbon (Basso et al., 2012).

On the other hand, soil erosion in some parts of southern Italy has been shown to be associated with specific types of changes in land use as well being promoted by agricultural policy. The application of the $\mathrm{F}$ measure of Reg. CE 2078/92, for instance, which implies a 20 -year period of set-aside for remodeled areas, is thought to cause an increase in soil erosion and degradation in southern Italy (Piccarreta et al., 2006).

\section{Conclusions and research needs}

Soil degradation processes in Italy not only have specificities with respect to northern European countries, but also to the other Mediterranean nations. In fact, if the impact of soil sealing, organic matter decline, and soil compaction are on average comparable to many other countries, landslides (involving/evolving on soils), soil erosion, and soil salinization often cause more damage in Italy than in most other parts of Europe. On the other hand, the fight against soil degradation is certainly more difficult in Italy than in other European countries because of the high environmental variability that means that application of soil and water conservation systems has to be finely tuned (Corti et al., 2013).

The most important driving forces of soil degradation are unfavorable soil and climate conditions coupled with poor environmental management, improper land planning, and bad agricultural husbandry. Among the different drivers, careless soil and land management of fragile environments (the responsibility of both public administrators and farmers) is the most important cause of soil degradation (Terribile et al., 2013).

Driving forces of soil degradations act on different levels: national, regional, municipal council and the farm. Therefore, the only response to combat land degradation is represented by integrated policy measures carried out on different spatial levels (Salvati et al., 2011).

The soil degradation process that causes the most damage in Italy is certainly the irreversible loss of land caused by urbanization and other non-agricultural uses, which often affects the most fertile soils of the plains. At present, among the different services that are lost with soil sealing, the diminished capability to produce food is particularly relevant, as it increases the gap between the Italian primary sector with the other developed countries in terms of food self-sufficiency. Soil sealing is particularly widespread in all flat areas, exactly where landslides and floods cause more damage.

Soil erosion and mass movements are still the most widespread forms of soil degradation in many regions of Italy. Landslides and floods, soil organic matter decline, and loss of biodiversity are all linked to water erosion. Besides reducing soil fertility, water erosion impairs several other eco-services, e.g. quality of foods and landscape, and biodiversity.

Further less devastating and less visible but still widespread processes are threatening Italian soils. Among them, soil compaction is assuming an important role as a consequence of the increasing use of heavy machinery for many agricultural practices in soils with a poor organic matter content. The risk of soil salinization and sodification is also destined to increase as a consequence not only of intensified competition among different water uses, but also because of the diffusion of excessive land leveling in soils formed from marine sediments. 
Many other still less visible and less known soil degradation processes affect the soil resources of Italy, among them, the loss of the cultural value of soil, which is often accompanied by the decrease in pedodiversity, and the loss of the traditional landscapes (Dazzi and Lo Papa, 2013). The process is mainly caused by crop intensification, practised on unsuitable soils or with improper agro-techniques, and is linked to the increase in hydrological disorder and geomorphological risk. But the relevance of this process is also to be found in the consequences of damage to the natural beauty of the landscape, as well as in the worsening of soil suitability for quality crops (Costantini and Barbetti, 2008). The degradation process is often underestimated, since Italy is still one of richest places in the world in terms of soil and landscape diversity, but the rapid disappearance of the cultural value of soil means our landscapes are becoming less and less attractive every day.

The picture outlined in this short review helps highlight some of the research needs to which soil sciences can be directed, in collaboration with the other agricultural sciences. First of all, there is the need to improve our basic knowledge. Our understanding about many soil degradation processes in Italy is still incomplete, both because some processes have still not been much investigated, and since the great Italian pedodiversity has not yet been completely surveyed and made available through online databases.

Reliable, sensitive, and locally validated models are still not available, especially for complex degradation processes such as soil water and mass erosion (Dazzi and Lo Papa, 2013). Monitoring soil characteristics and qualities must rely upon direct assessment or intensive validation, possibly by means of proximal and remote sensors (see, for example, http://www.isoil.info/). We also do not know much about the resilience of different soils against degradation processes and their reaction to the measures foreseen under the current European agricultural policy (Bazzoffi and Zaccarini Bonelli, 2011). Finally, cooperation between policy makers and stakeholders is still in its infancy, and even more so with regards to the integration of soil and agronomic sciences with the social and economic disciplines. These factors often limit the impact and effectiveness of scientific research and results on land planning and management.

\section{References}

Addiscott TM, 2010. Entropy, non-linearity and hierarchy in ecosystems Geoderma 160:57-63.

Alvaro-Fuentes J, Paustian K, 2011. Potential soil carbon sequestration in a semiarid Mediterranean agroecosystem under climate change: Quantifying management and climate effects. Plant Soil 338:261-72.

APAT (Agenzia per la protezione dell'ambiente e per i servizi tecnici), 2007. Il suolo la radice della vita. ISPRA, Roma, Italy, pp 117.

Basso B, de Simone L, Cammarano D, Martin EC, Margiotta S, Grace PR, Yeh ML, Chou TY, 2012. Evaluating responses to land degradation mitigation measures in southern Italy. Int. J. Environ. Res. 6:367-80.

Bazzoffi P, Zaccarini Bonelli C, 2011. Cross compliance GAEC standards implemented in Italy: Environmental effectiveness and strategic perspectives. Ital. J. Agron. 6 (Suppl 1):1-5.

Busoni E, Salvador Sanchis P, Calzolari C, Romagnoli A, 1995.Mass movement and erosion hazard patterns by multivariate analysis of landscape integrated data: the Upper Orcia River Valley (Siena, Italy) case. Catena 25:169-85.

Chen Z, Lu C, Fan L, Wu H, 2011. Effects of land use change on soil organic carbon: a review. Acta Ecol. Sinica 31:5358-71.

Conant RT, Paustian K, Elliott ET, 2001. Grassland management and conversion into grassland: Effects on soil carbon. Ecol. Appl.
11:343-55

Consiglio dei Ministri, 2012. Comunicato stampa n. 45 del 14/09/2012. Available from: http://www.governo.it/Governo/ConsiglioMinistri/ dettaglio.asp?d=69146

Corti G, Cocco S, Brecciaroli G, Agnelli A, Seddaiu G, 2013. Soil management. In: E.A.C. Costantini and C. Dazzi (eds) The soils of Italy. Springer, Berlin, Germany, pp 247-94.

Costantini EAC, Barbetti R, 2008. Environmental and visual impact analysis of viticulture and olive tree cultivation in the province of Siena (Italy). Eur. J. Agron. 28:412-26.

Costantini EAC, Barbetti R, Fantappiè M, L'Abate G, Lorenzetti R, Magini S, 2013. Pedodiversity. In: The soils of Italy. In: E.A.C. Costantini and C. Dazzi (eds.) World soils book series. Springer, Berlin, Germany, pp 105-78.

Costantini EAC, Urbano F, Aramini G, Barbetti R, Bellino F, Bocci M, Bonati G, Fais A, L'Abate G, Loj G, Magini S, Napoli R, Nino P, Paolanti M, Perciabosco M, Tascone F, 2009. Rationale and methods for compiling an atlas of desertification in Italy. Land Degr. Dev. 20:261-76.

Crescimanno G, Marcum KB, Reina C., Versaci A, 2009. Investigating soil-plant relationships for sustainable management of irrigation with saline water in a Sicilian vineyard. 5th International Conference on Sustainable Water Resources Management, Halkadiki, Greece.

Dazzi C, 2006. Acque saline e qualità del suolo. Ital. J. Agron. 1 (Suppl 3):467-74.

Dazzi C, Laudicina VA, Lo Papa G, Monteleone S, Scalenghe R, 2005. Soils with Gypsic horizons in Southern Sicily, Italy. In: A. Faz Cano, R. Ortiz, A.R. Mermuteds (eds.) Sustainable use and management of soils - Arid and semiarid regions - Advances in GeoEcology, vol. 36. Catena Verlag, Reiskirchen, Germany, pp 13-22.

Dazzi C, Monteleone S, 2007. Anthropogenic processes in the evolution of a soil chronosequence on marly-limestone substrata in an Italian Mediterranean environment. Geoderma 141:201-9.

Dazzi C, Lo Papa G, 2013. Soil threats. In: E.A.C. Costantini and C. Dazzi (eds) The soils of Italy. Springer, Berlin, Germany, pp 205-46.

Durgin P, 1984. Subsurface drainage erodes forested granitic terrane. Phys. Geogr. 5:24-39.

European Commission, 2006a .Communication from the Commission to the Council, the European parliament, the European economic and social committee and the committee of the regions. Thematic strategy for soil protection. (COM(2006)231 final). European Commission, Brussels, Belgium.

European Commission, 2006b. Accompanying document to the Communication from the Commission to the Council, the European Parliament, the European Economic and Social Committee and the Committee of the Regions - Thematic Strategy for Soil Protection - Summary of the impact assessment (SEC(2006)1165). European Commission, Brussels, Belgium.

European Commission, 2012. Report from the commission to the European parliament, the council, the European economic and social committee and the committee of the regions. The implementation of the Soil Thematic Strategy and ongoing activities (COM/2012/046 final). European Commission, Brussels, Belgium.

EEA (European Environment Agency), 2012.Climate change, impacts and vulnerability in Europe 2012, Report No 12/2012, p 300.

Fantappiè M, L'Abate A, Costantini EAC, 2010. Factors influencing soil organic carbon stock variations in Italy during the last three decades. In: A. Zdruli, S. Pagliai, M. Kapur and P. Faz Cano (eds) Land degradation and desertification: assessment, mitigation and remediation. Springer-Verlag, Berlin-Heidelberg-New York, pp 435-65.

Fantappiè M, L'Abate G, Costantini EAC, 2011. The influence of climate change on the soil organic carbon content in Italy from 1979 to 
2008. Geomorphology 135:343-52.

FAO (Food and Agriculture Organization), 2013. FAO food price index. Available from: http://www.fao.org/worldfoodsituation/wfs-home/ foodpricesindex/en/

Fornasiero A, Putti M, Teatini P, Ferraris S, Rizzetto F, Tosi L, 2003. Monitoring of hydrological parameters related to peat oxidation in a subsiding coastal basin south of Venice, Italy. IAHS-AISH Publ. 278:458-62.

Freppaz M, Celi L, Marchelli M, Zanini E, 2008. Snow removal and its influence on temperature and $\mathrm{N}$ dynamics in alpine soils (Vallée d'Aoste, northwest Italy). J. Plant Nutr. Soil Sci. 171:672-80.

Huber S, Prokop G, Arrouays D, Banko G, Bispo A, Jones RJA, Kibblewhite MG, Lexer W, Möller A, Rickson RJ, Shishkov T, Stephens M, Toth G, Van den Akker JJH, Varallyay G, Verheijen FGA, Jones AR, 2008. Environmental assessment of soil for monitoring - volume I: Indicators and criteria. EUR 23490 EN/1. Office for the Official Publication of the European Communities, Luxembourg, p 339.

Iamarino M, Terribile F, 2008. The importance of andic soils in mountain ecosystems: a pedological investigation in Italy. Eur. J. Soil Sci. 59:1284-92.

ISPRA (Istituto Superiore per la Protezione e la Ricerca Ambientale), 2013. Linee guida per la valutazione del dissesto idrogeologico e la sua mitigazione attraverso misure e interventi in campo agricolo e forestale. Manuali e Linee Guida 85/2013. ISPRA, Rome, Italy, p 98.

Johnston AE, 1991. Soil fertility and soil organic matter. In: W.S. Wilson (ed.) Advances in soil organic matter research: the impact on agriculture and the environment. R. Soc. Chem. Cambridge Royal Society of Chemistry, Cambridge, UK, pp 297-314.

Jones RJA, Hiederer R, Rusco E, Montanarella L, 2005. Estimating organic carbon in the soils of Europe for policy support. Eur. J. Soil Sci. 56:655-71.

JRC (Joint Research Centre), 2011. The state of soil in Europe. Publication Office of the European Union, Luxembourg, p 78.

Körschens M, Weigel A, Schulze E, 1998. Turnover of soil organic matter (SOM) and long-term balances - tools for evaluating sustainable productivity of soils. Zeitschr. Pflanzener. Boden. 161:409-24.

Li GY, Zhou WF, 1999. Sinkholes in karst mining areas in China and some methods of prevention. Eng. Geol. 52:45-50.

Loveland P., Webb J., 2003. Is there a critical level of organic matter in the agricultural soils of temperate regions: a review. Soil Till. Res. 70:1-18.

MiPAAF (Ministero delle Politiche Agricole Alimentari e Forestali), 2012. Costruire il futuro: difendere l'agricoltura dalla cementificazione. Perdita di terreni agricoli, approvvigionamento alimentare e impermeabilizzazione del suolo. Available from: http://www. politicheagricole.it/flex/cm/pages/ServeAttachment.php/L/T/D/

MiPAAF (Ministero delle Politiche Agricole Alimentari e Forestali), 2013. Applicazione dei criteri biofisici al territorio italiano per la revisione delle zone svantaggiate intermedie (ex art. 19 REG. CE 1257/99). Ministero delle Politiche Agricole Alimentari e Forestali, Roma, Italy, p 41.

Munafò M, Salvati L, Zitti M, 2013. Estimating soil sealing rate at national level - Italy as a case study. Ecol. Indic. 26:137-40.

OECD (Organisation for Economic Co-operation and Development), 2001. Environmental indicators for agriculture - vol. 3: Methods and results, glossary, OECD Publ., Paris, France, 2:410.

Pagliai M, Pellegrini S, Vignozzi N, Rousseva S, Grasselli 0, 2000. The quantification of the effect of subsoil compaction on soil porosity and related physical properties under conventional to reduced management practices. Adv. Geoecol. 32:305-13.
Pal DK, Bhattacharyya T, Chandran P, Ray SK, Satyavathi PLA, Durge SL, Raja P, Maurya UK, 2009. Vertisols (cracking clay soils) in a climosequence of Peninsular India: evidence for Holocene climate changes. Quatern. Int. 209:6-21.

Panagos P, Van Liedekerke M, Montanarella L, Jones RJA, 2008. Soil organic carbon content indicators and web mapping applications. Environ. Model. Softw. 23:1207-9.

Phillips JD, 1995. Self-organization and landscape evolution. Progr. Phys. Geogr. 19:309-21.

Phillips JD, Gares PA, Slattery MC, 1999. Agricultural soil redistribution and landscape complexity. Landscape Ecol. 14:197-211.

Piccarreta M, Capolongo D, Boenzi F, Bentivenga M, 2006. Implications of decadal changes in precipitation and land use policy to soil erosion in Basilicata, Italy. Catena 65:138-51.

Robinson DA, Lebron I, Vereecken H, 2009. On the definition of the natural capital of soils: a framework for description, evaluation, and monitoring. Soil Sci. Soc. Am J. 73:1904-11.

Salvati L, 2012. The spatial nexus between population growth and land degradation in a dry Mediterranean region: a rapidly changing pattern? Int. J. Sustain. Dev. World Ecol. 19:81-8.

Salvati L, Bajocco S, Ceccarelli T, Zitti M, Perini L, 2011. Towards a process-based evaluation of land vulnerability to soil degradation in Italy. Ecol. Indic. 11:1216-27.

Salvati L, Carlucci M, 2013. The impact of Mediterranean land degradation on agricultural income: a short-term scenario. Land Use Policy 32:302-8.

Salvati L, Mancini A, Bajocco S, Gemmiti R, Carlucci M, 2011. Socioeconomic development and vulnerability to land degradation in Italy. Reg. Environ. Change 11:767-77.

Schils R, Kuikman P, Liski J, van Oijen M, Smith P, Webb J, Alm J, Somogyi Z, van den Akker J, Billett M, 2008. Review of existing information on the interrelations betweensoil and climate change. CLIMSOIL, Final Report. 16 December 2008. Available from: http// ec.europa.eu/environment/soil/pdf/climsoil_report_dec_2008.pdf

Smith P, Davies CA, Ogle S, Zanchi G, Bellarby J, Bird N, Boddey RM, McNamara NP, Powlson D, Cowie A, van Noordwijk M, Davis SC, Richter DDB, Kryzanowski L, van Wijk MT, Stuart J, Kirton A, Eggar D, Newton-Cross G, Adhya TK, Braimoh AK, 2012. Towards an integrated global framework to assess the impacts of land use and management change on soil carbon: current capability and future vision. Global Change Biol. 18:2089-101.

Targulian VO, Krasilnikov PV, 2007. Soil system and pedogenic processes: self-organization, time scales, and environmental significance. Catena 71:373-81.

Terribile F, Basile A, De Mascellis R, Iamarino M, Magliulo P, Pepe S, 2007. Landslide processes and Andosols: the case study of the Campania region, Italy. In: 0. Arnalds (ed.) Soils of volcanic regions in Europe. Springer Verlag, Berlin-Heidelberg, Germany, pp 545-563.

Terribile F, Basile A, Bonfante A, Carbone A, Colombo C, Langella G, Iamarino M, Manna P, Minieri L, Vingiani S, 2013. Future soil issues. In: E. Costantini and C. Dazzi (eds) The soils of Italy. Springer, Berlin, Germany, pp 303-348.

Tóth G, 2008. Updated map of salt affected soils in the European Union. In: G. Tóth, L. Montanarella, E. Rusco (eds.) Threats to soil quality in Europe. EUR 23438 - Scientific and Technical Research series. Office for Official Publications of the European Communities, Luxembourg, pp 61-74. 